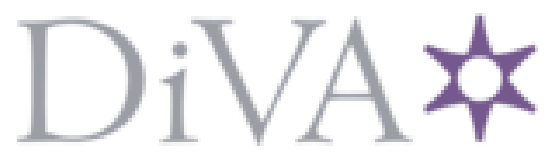

http://www.diva-portal.org

This is the published version of a paper published in Gerontechnology.

Citation for the original published paper (version of record):

Martina, B., Kjellström, S., Malmberg, B., Björklund, A. (2011)

Personal emergency response system (PERS) alarms may induce insecurity feelings.

Gerontechnology, 10(3): 140-145

http://dx.doi.org/10.4017/gt.2011.10.3.001.00

Access to the published version may require subscription.

N.B. When citing this work, cite the original published paper.

Open Access journal (http://gerontechnology.info/index.php/journal/article/view/1488)

Permanent link to this version:

http://urn.kb.se/resolve?urn=urn:nbn:se:hj:diva- 17030 


\title{
Personal emergency response system (PERS) alarms may induce insecurity feelings
}

\author{
Martina Boström MSc \\ Sofia Kjellström PhD \\ Bo Malmberg PhD \\ Institute of Gerontology, School of Health Sciences, \\ Jönköping University, Jönköping, Sweden \\ E: martina.bostrom@hhj.hj.se \\ Anita Björklund PhD \\ Department of Rehabilitation, School of Health Sciences, \\ Jönköping University, Jönköping, Sweden
}

\begin{abstract}
M. Boström, S. Kjellström, B. Malmberg, A. Björklund. Personal emergency response system (PERS) alarms may induce insecurity feelings. Gerontechnology 2011; 10(3):......; doi:10.4017/gt.2011.10.3.001.00 Personal emergency response system (PERS) alarms have been used in Sweden since 1974 to enable older people to age safely at home. Despite this long use, we found no studies describing independent older users' opinions of these devices. Aim Our aim was to describe how people living in Swedish independent senior housing perceive the alarms and to highlight their wishes for further developments and innovations. Methods We conducted four focus group interviews with residents of senior housing who used or had used a PERS alarm and analysed the data qualitatively for latent content. Results The data analysis revealed five themes in participants' opinions and feelings about the PERS alarms: (i) safety, (ii) anxiety, (iii) satisfaction, (iv) being informed, and (v) older persons as active innovators. Conclusion The 40-year-old Swedish PERS used in senior housing seems to limit rather than liberate users in their daily lives and cause feelings of insecurity rather than security. Older Swedish people require a more personalized alarm with a built-in positioning system that would allow them a greater range of movement beyond their homes.
\end{abstract}

Keywords: focus groups, inclusive design, PERS, qualitative research

Personal emergency response system (PERS) are intended to promote safety, independence, and confidence to perform everyday activities ${ }^{1-5}$.The devices are worn on the wrist or hanging around the neck, so the older person can get in telephone contact with an emergency service center (ESC) if needed. It is often the ESC that initially informs the old persons about their PERS. Current studies include PERS in the concept of everyday technology ${ }^{6-8}$ or focus on older people with disabilities, in need of care or older people living in nursing homes ${ }^{5,9-11}$. We found no studies from the more independent older user's point of view; therefore the aim of this study was to elicit and analyse opinions and feelings about PERS technology from people living in Swedish independent senior housing and to highlight their wishes regarding its further development and innovation.

'Senior housing' has become established in Sweden and is intended for active, independent old people with minor needs for home help services who want to live on their own amidst people like themselves.

\section{Methods}

The participants were recruited by head administrators of a municipality in the south of Sweden and five focus groups were formed. In total 45 older persons participated, 6797 years old, all widowed or single (Table 1), stated good health and who had none 




Figure 1. Analysis of the experimental data

or limited home help services. All but five were using PERS; the five who did not use them at the time of the study had previous experience from them.

The questions used in the focus group were formulated in line with Morgan and Kreuter $^{12}$. Focus areas were consequently tested on a pilot group of older persons who were not participants in this study. At the outset of the focus group interviews, the first author informed the interviewees of the reason for recording the interviews on audio-tape and video, emphasizing that they could decline participation at any time.

Each focus group began with an open introductory question, "Could you please describe your experiences of and your thoughts about technical developments through your life?" The interview then continued with open, semi-structured questions relating to three different focus areas that had to do with their PERS: (i) thoughts and experiences of PERS; (ii) current use and understanding of PERS; and (iii) wishes, reflections and thoughts about PERS in the future. Every focus group interview was audio-taped and video-recorded to secure reliability for analysis. Each focus group interview lasted for about 1-2 hours.

Latent content analysis as described by Krippendorff ${ }^{13}$ was applied (Figure 1). Meaning units were underlined and condensed as closely as possible to the original text. Every condensation was further abstracted and given a code, ascribed as a label representing a degree of interpretation ${ }^{13}$. Related codes were grouped into larger groups (Table 2) comprising five different themes in participants' views of current and possible future PERS alarms. The five themes were presented at two different workshops during a content analysis course and each step of the analysis process was discussed thoroughly. Additionally, after the analysis the results were reported back to the participants in the focus groups for member checking, by sharing all of the findings with participants for trustworthiness ${ }^{14}$. The named themes proved to be consistent for every focus group.

Table 1. Description of focus groups of widowed or single adults, 67-93 years old, living in senior housing, and acquainted with PERS

\begin{tabular}{c|ccc}
\hline $\begin{array}{c}\text { Focus } \\
\text { Group }\end{array}$ & $\begin{array}{c}\text { Number of } \\
\text { participants }\end{array}$ & $\begin{array}{c}\text { Dwelling } \\
\text { location }\end{array}$ & Gender \\
\hline 1 & 9 & Urban & All male \\
2 & 7 & Urban & All female \\
3 & 10 & Country & 2 males, 8 females \\
4 & 13 & Urban & 2 males, 11 females \\
5 & 6 & Country & 1 male, 5 females \\
\hline
\end{tabular}


Table 2. Analysis steps in the uninformed theme

\begin{tabular}{|c|c|c|c|}
\hline Response transcript & Meaning & Condensation close to text & Code \\
\hline $\begin{array}{l}\text { I don't know... I.... Does it } \\
\text { work in other places or just } \\
\text { here? (Focus group 2, female) }\end{array}$ & $\begin{array}{l}\text { Does it work in other } \\
\text { places or just here? }\end{array}$ & $\begin{array}{l}\text { Wonders if it works in other } \\
\text { places or just here }\end{array}$ & Wonder \\
\hline $\begin{array}{l}\text { We got to find the information } \\
\text { ourselves ... no, no-one has } \\
\text { said } \\
\text { anything ... that it reaches } \\
\text { further than inside... (Focus } \\
\text { group } 3, \text { male) }\end{array}$ & $\begin{array}{l}\text { Find the information } \\
\text { themselves, no-one } \\
\text { has said anything }\end{array}$ & $\begin{array}{l}\text { Says that they had had to find } \\
\text { the information themselves } \\
\text { because there hadn't been } \\
\text { anyone who had said that it } \\
\text { reaches further than inside }\end{array}$ & $\begin{array}{l}\text { Lacks } \\
\text { information }\end{array}$ \\
\hline $\begin{array}{l}\text { Does it work in the dining- } \\
\text { hall then? That's not certain ... } \\
\text { no .... (Focus group } 4 \text {, } \\
\text { female) }\end{array}$ & $\begin{array}{l}\text { Does the alarm work } \\
\text { in the diner? }\end{array}$ & $\begin{array}{l}\text { Wonders if it works in the } \\
\text { dining-hall? Expresses } \\
\text { uncertainty. }\end{array}$ & $\begin{array}{l}\text { Wonder, } \\
\text { uninformed }\end{array}$ \\
\hline
\end{tabular}

The study was conducted in accordance with the four individual protection requirements of research and approved by the Regional Ethics Committee.

\section{Results}

The results are structured in relation to the five themes emanating from the data analysis.

\section{Safe and freely}

Participants said that they want to have the opportunity to move about safe and freely both inside and outside the senior housing. Existing PERS were therefore considered not quite sufficient because of their limited reach in public areas, in the garden or even on the balcony. Participants talked about their own experiences and about their observations of other people using the system.

"No, but you wish that that security detail would work, that there was some range to this for them ... these old men are so alert ... they're running about, you know, like billygoats" (Focus group 1, male).

The interviewees saw themselves as competent, conscious, and quick to learn about new technology. They described themselves as capable of understanding and using the latest technological devices as long as they had accessible and adapted support and information. Throughout their lives they had developed technical knowledge and they didn't want to be seen as incompetent or unable to adjust to new technology or information about new technology just because they had moved into senior housing.

"Because as a matter of fact ... we're not stupid because ... because we moved in here ... or because we fall. We have experience! So that ... we can very well ... take in the technical things, there don't have to be manuals as such, but how it works" (Focus group 2, female).

The participants were dissatisfied with and critical of the limitations their PERS set on their movements. In particular, they felt that the lack of new technical innovations in the alarm system, such as the inclusion of a global positioning system (GPS), was a clear indication that their needs were not considered priorities in society.

\section{Anxious, afraid and insecure}

The participants frequently expressed feelings of anxiety, fear, and insecurity associated with an inadequate PERS. The security alarm did not always work when they most needed it, and staff were not always within reach. Their experience of fear and insecurity at night was even more pronounced.

To achieve greater security and a feeling of safety, the participants had developed alternative strategies. Staying in the building where there were always other people 
present was one strategy; another was to scream so loud that someone nearby could hear them or deny that accidents can happen outside the home. The general feeling was that it was their own fault if they moved out of the reach of their alarm.

"If you go to places where the alarm doesn't reach, then you have yourself to blame" (Focus group 3, female).

Besides the dependence on the people around them, the participants had also tried to find alternative products that would increase their security in everyday life, such as a mobile phone, a non-slip mat, or a walking frame on wheels.

\section{Satisfied}

Quite a few participants expressed satisfaction with their PERS and had adapted to the situation. In particular, these interviewees reported that despite false alarms or repeated alarms, health care staff were always patient.

\section{Uninformed}

Opinions seemed to be divided and confused when it came to whether the alarm reached to the threshold of the living quarters or to the elevator or even to the garden. The participants wished for improvements in the information they received, and for more liberty to choose whether or not they should be using an alarm. Also, they wanted more information about different types of alarms available. They were disappointed in the lack of information as well as being required using their alarm in everyday life.

"I talked to someone ... he lives in the block of flats that you can see there. And he believed, you see, it was Hans. He said, my alarm, you see, it reaches here, he said ... No, I said, it doesn't. Sound the alarm now, I said. Then we'll see. So he did. It didn't give off any sound. He had only imagined that it reached everywhere ..." (Focus group 3 , female)

Some participants reported that their rooms had alarm buttons that had been installed long time ago that no longer worked, which was perceived as misleading. They were also distressed that some places had emergency buttons and others did not. Some of the participants had been given the option to live in senior housing without a PERS, while others had not been given this option when they moved in, and this disparity led to confusion.

\section{Active innovators}

The participants said they wanted an alarm system that would enable them to move freely and safely in the community. The alarm should be waterproof, easy to use and personalized and include a positioning system. The alarm should be automatically connected to the closest health care personnel since this would minimize the time they had to wait for help. They also suggested that the ideal alarm system would automatically sound an alert in case of the wearer's disorientation, loss of speech or loss of consciousness, as well as in an accident.

"As soon as you fell down and the body reached the floor, then ... the alarm would sound..." (Focus group 4, female).

Participants thought it did not make sense to involve relatives in the emergency procedure, and preferred in that case to have contact with their loved ones by telephone. On the other hand, they stressed that they would not want an enhanced alarm system that would make human contact completely unnecessary. They also raised the financial worry that more advanced technology could lead to higher costs that they might not be able to afford.

"I mean, maybe I could get triple the fee if I want an alarm that works down in my store room or in the refuse room or wherever I am, and not to mention if I go five hundred metres away from this house" (Focus group 5 , male)

Despite any misgivings or complaints, participants all said that the alarm did save lives and that, whatever the cost they were still 
dependent on it. They preferred the alarm to be inconspicuous, preferably in the form of a necklace that could be hidden inside their clothing. Alarms in the form of an earring pendant or other jewellery were not considered such a good idea.

\section{Discussion}

Because users' knowledge of what new technologies can realistically be expected to do is limited, it remains difficult to outline further practical development of PERS to meet their needs or desires. It is possible that similar studies in other contexts may arrive at different results. Despite the aim of personal emergency response systems to provide security, this study shows that they may instead cause insecurity in those they are most meant to reassure.

There are numerous theories that might explain how to promote or hinder successful aging. The social structure theory ${ }^{15}$ suggests that positive attitudes towards the elderly and their integration in society may increase their self-confidence. The results from this study, concerning the limitations of PERS and the participants' rejection of a system that stigmatizes them, show that PERS does not increase their self-confidence. On the contrary, it causes insecurity and consequently hinders their integration into society.

The participants also felt insecurity, fear and anxiety, especially at night, as also mentioned by Porter ${ }^{10}$ and by San Miguel ${ }^{4}$ although the possibility that the interviewees' increased insecurity was a consequence of living alone could not be excluded. To compensate for these feelings the older persons in our study used different strategies to allow them to age successfully. Those compensations are described in the model of selective optimization with compensation ${ }^{16}$. Briefly, this model proposes that older people who can maximize support from their environment are the ones who will become capable of ageing successfully. As mentioned earlier, some strategies employed by participants in this study included staying inside the building, screaming for help, and denying the possibility of an accident. Other strategies included compensation with simpler techniques such as using an anti-slip mat in the shower.

Östlund ${ }^{6}$ stresses that older persons should be seen as active consumers in the technological development of assistive devices. This was confirmed in this study, since the older persons expressed concrete desires and wishes for further development. They also saw themselves as technically competent and aware of alternative techniques i.e. GPS, which they believed would increase their freedom to move about safely. In a pilot study of the Lighthouse Alarm and Locator $^{17}$ older people were asked to test and describe experiences of using a new mobile alert system with enhanced features such as a positioning system and increased surveillance. Their results revealed, amongst other things, that the older persons became more active, which, in addition to improved freedom, was considered an important factor for improving their health.

To meet the needs and promote the quality of life for people in their older years it may also be important to adopt practical and policy solutions ${ }^{18}$. One important part of developing personalized assistive technologies for older adults in the future may therefore be to promote natural arenas for exchanging ideas. Coleman ${ }^{19}$ advocates inclusive design as a strategy for improving the quality and usability of products and services for people of all abilities in all situations. This study reveals that older people living fairly independently in senior housing are in need of a PERS with a built-in positioning system that would allow them greater geographic, and hence, personal and social, range of freedom.

\section{References}

1. Kort YS de. A tale of two adaptations, coping processes of older persons in the domain of independent living. PhD thesis. Eindhoven: Eindhoven University of Technology; 1999 


\section{PERS and insecurity}

2. Magnusson L, Hanson E, Borg M. A literature review study of Information and Communication Technology as a support for frail older people living at home and their family carers. Technology \& Disability 2004;16(4):223-235

3. Miskelly FG. Assistive technology in elderly care. Age and Ageing 2001;30(6):455-458; doi:10.1093/ageing/30.6.455

4. Miguel KDS. Personal emergency alarms: What impact do they have on older people's lives? Australasian Journal on Ageing 2008;27(2):103-105; doi:10.1111/j.17416612.2008.00286.x

5. Porter EJ. Moments of Apprehension in the Midst of a Certainty: Some Frail Older Widows' Lives with a Personal Emergency Response System. Qualitative Health Research 2003;13(9):1311-1323; doi:10.1177/1049732303253340

6. Östlund B. Gammal är äldst. En studie av teknikens betydelse i äldre människors liv. [Old people are the most experienced. A study of the meaning of technology in old people's every day life]. Linköping Studies in Arts and Sciences No 129. Linköping: Linköping University; 1995

7. Hagberg J-E. Livet genom tekniklandskapet Livslopp, åldrande och vardagsteknikens förändring [Life through the landscape of technique. Life course - ageing and the changes in everyday technology]. Working Paper from National Institute for the Study of Ageing and Later Life (NISAL) Linköping University; 2008; pp 7-44.

8. Larsson A. Everyday life amongst the oldest old - descriptions of doings and possession and use of technology. Linköping: Faculty of health sciences Linköping University; 2009

9. Porter EJ, Ganong LH. Considering the Use of a Personal Emergency Response System: An Experience of Frail, Older Women. Care Management Journals 2002;3(4);192198; doi:10.1891/cmaj.3.4.192.57452

10. Porter EJ. Wearing and using personal emergency response system buttons: older frail widows' intentions. Journal of Gerontological Nursing 2005;31(10):26-33

11. Wälivaara BM, Andersson $S$, Axelsson K. Views on technology among people in need of health care at home. International Journal of Circumpolar Health 2009;68(2):158-169

12. Morgan D, Kreuter R. The focus group kit. Thousand Oaks: Sage; 1998

13. Krippendorff K. Content Analysis. An introduction to its methodology. 2nd edition. Thousand Oaks: Sage; 2004

14. Eresswell JW. Qualitative inquiry and research design - Choosing among five traditions. Thousand Oaks: Sage; 1998

15. Bengtson VLGD, Putney N, Silverstein M. Handbook of theories of aging. 2nd edition. New York: Springer; 2009

16. Baltes PB, Baltes MM. Psychological perspective on successful aging: The model of selective optimization with compensation. New York; NYCU; 1990

17. Melander-Wikman A, Jansson M, Hallberg J, Mörtberg C, Gard G. The Lighthouse Alarm and Locator trial - A pilot study. Technology and Health Care 2007;15(3):203-312

18. Burgess AM, Burgess CG. Aging-in-Place: Present Realities and Future Directions. Forum on public policy; 2007. ISSN: 1556$763 X$.

19. Coleman R, Myerson J. Improving Life Quality by Countering Design Exclusion. Gerontechnology 2001;1(2):88-102; doi:2001.01.02.002.00 